\title{
Comparative study of the Fenwal and Pall microaggregate filters used for the production of leucocyte-poor blood
}

\author{
JENNIFER G TRELEAVEN, KG PATTERSON, J BLAGDON
}

From the Brentwood Blood Transfusion Centre, Brentwood, Essex

SUMMARY Eighty units of whole blood in its third week of shelf-life were filtered through the Pall or Fenwal microaggregate filter. Half of these units were centrifuged before filtration. White cell removal was approximately $30 \%$ for the Fenwal filter both with and without prior centrifugation; for the Pall filter, removal was $7 \%$ without centrifugation and $30 \%$ with centrifugation.

It is suggested that these simple filters are a useful way of reducing both platelet and white cell content of blood administered to patients requiring multiple transfusion. Their use may delay development of white cell and platelet antibodies obviating the use of washed or frozen cells in these patients.

It is well recognised that patients receiving multiple blood transfusions develop non-haemolytic transfusion reactions, although the frequency with which such reactions can be attributed to white cell antibodies has been the subject of much controversy. Kevy et $a^{1}{ }^{1}$ were unable to demonstrate any correlation between the presence of leucoagglutinins and the occurrence of transfusion reactions. Payne et $\mathrm{al}^{2}$ found white cell antibodies in the sera of $67 \%$ of their patients having febrile transfusion reactions, whereas Andre et $\mathrm{al}^{3}$ observed white cell or platelet antibodies or both, in only $31 \%$ of a series of samples from patients with febrile reactions.

The quantity of white blood cells required to initiate a non-haemolytic transfusion reaction appears to differ widely from patient to patient, as does the exposure time to the foreign antigens. Perkins et $\mathrm{al}^{4}$ found that the amount of white cells necessary to cause a rise in temperature of $1^{\circ} \mathrm{C}$ varied from $0.25 \times 10^{9} / 1$ to $>2.5 \times 10^{9} / 1$ in different patients. It seems certain, however, that eventually the majority of patients on chronic transfusion regimens using whole blood develop non-haemolytic transfusion reactions and that these are in the main attributable to leucocyte or platelet antibodies, or both.

The aim of this study was to evaluate the effectiveness of leucocyte and platelet filtration by two simple and inexpensive blood filters. Up to the present time these have been used to protect the pulmonary, cerebral and systemic microcirculations from vascular occulsion by microaggregates, in patients receiving massive stored blood transfusions. Wenz et $a l^{5}$ studied the Pall microaggregate filter and was able to remove $60 \%$ of the total white cell mass, virtually eliminating the neutrophils in some units. In his study, the frequency of febrile transfusion reactions was reduced by $95 \%$.

In this study, the Pall microaggregate filter is compared with the Fenwal microaggregate filter, both of which can be used for multiple units of blood, and can be used at the bedside.

\section{Material and methods}

Eighty units of whole blood were used; all units were more than 15 days old, but less than 21 days old. Blood in its third week of shelf-life was used in order to maximise the amount of microaggregates present. As McNamara et $a l^{6}$ and Swank $^{7}$ have shown that preliminary centrifugation of blood increased microaggregate formation, half the units used in this study were spun at $5000 \mathrm{~g}$ for $10 \mathrm{~min}$ before filtration. Twenty units of uncentrifuged, and 20 units of centrifuged blood were filtered using Fenwal filters. Similarly, 20 units of both centrifuged and uncentrifuged blood were filtered through Pall filters.

Each unit of blood was allowed to pass through the filter for between 15 and $20 \mathrm{~min}$. Before filtration, 
it was put on a rotary mixer for $10 \mathrm{~min}$ to resuspend the cells. All units were stored at $4^{\circ} \mathrm{C}$ before use. Four units of $\mathrm{ABO}$ compatible blood were put through each filter, and it was then discarded. After filtration, each unit was collected in a measuring cylinder.

Samples were taken for estimation of haemoglobin white cell count and platelet count on the Coulter $S$ plus counter, before filtration (but after mixing on the rotary mixer) and after filtration, following mixing of the contents of the measuring cylinder. In addition, samples were analysed by the Hemalog D automated differential counter before and after filtration. Ten thousand cells were counted in the peroxidase channel of the instrument for each sample analysed before filtration. One thousand cells were counted in the post-filtration samples, which were sufficiently leucopenic to prevent the instrument counting 10000 cells within the 45 -second sampling time.

All blood units were weighed, and the volume of blood before and after filtration, ascertained. Absolute white cell and platelet numbers before and after filtration could then be calculated.

\section{Results}

The results are shown in the Table. It will be seen that both the Fenwal and the Pall filters are equally effective at removing white cells, provided that the blood units have been centrifuged first. Both filters removed $29 \%$ of the total white cells present and approximately $40 \%$ of the platelets. The Fenwal filter removes $28 \%$ of the white cells when the units are uncentrifuged, whereas the Pall filter removes only $7 \%$.

The average absolute neutrophil content of the filtered units can also be seen from the Table, and is comparable for both filters, when the units have been spun before filtration. The percentage removal of both lymphocytes and neutrophils is again comparable for the two filters, using centrifuged blood. Centrifugation improves removal of both neutrophils and lymphocytes by the Pall filter, and neutrophil removal by the Fenwal filter is unaffected by prior centrifugation.

The white cell count of each donor unit before filtration correlated in general with the white cell count of the leucocyte depleted unit after filtration; the higher the initial count, the greater the number of white cells present in the filtrate. The results show no deterioration in the performance of the filters with successive units of blood. Although the manufacturers of both filters state that multiple units may be processed through the same filter, only four units were processed through each filter in this study, as this is the average requirement for patients on chronic transfusion regimens.

Haemoglobin loss during the procedure is minimal and comparable for each method of preparation.

\section{Discussion}

The use of a Pall or Fenwal filter in the administration of blood to patients who will require frequent transfusion may delay the development of white cell and platelet antibodies, thereby prolonging the time interval before washed cell or liquid nitrogen frozen blood have to be used. In patients who have already developed antibodies and pyrexial reaction during transfusion, their use may allow antibody titres to decline, thereby again delaying the necessity of using washed or frozen cells.

The minimum number of white cells and platelets required to evoke an antibody response varies very widely from person to person; in some cases it is unlikely that filters removing approximately 30\% of white cells and $40 \%$ of platelets will be of any value in delaying the development of white cell and platelet antibodies. However, their use may be beneficial in other patients by delaying sensitisation to leucocytes and platelets.

Wenz et $a l^{5}$ has reported more efficient white cell removal than we have achieved in this study using similar methodology.

It is possible that this difference arises because our units of stored blood were placed on a rotary mixer before filtration and this could have disrupted

Performance of Fenwal and Pall microaggregate filters

\begin{tabular}{|c|c|c|c|c|c|c|c|}
\hline $\begin{array}{l}\text { Filter and } \\
\text { whether } \\
\text { centrifuged }\end{array}$ & $\begin{array}{l}\text { Mean removal } \\
\text { of } W B C(\%)\end{array}$ & $\begin{array}{l}\text { Mean removal } \\
\text { of platelets }(\%)\end{array}$ & $\begin{array}{l}\text { Mean loss of } \mathrm{Hb} \\
(\%)\end{array}$ & $\begin{array}{l}\text { Mean absolute } \\
\text { neutrophil content } \\
\text { after filtration } \\
\left(\times 10^{\circ} / l\right)\end{array}$ & $\begin{array}{l}\text { Mean absolute } \\
\text { lymphocyte } \\
\text { content after } \\
\text { filtration } \\
\left(\times 10^{\circ} / l\right)\end{array}$ & $\begin{array}{l}\text { Mean removal } \\
\text { of neutrophils } \\
(\%)\end{array}$ & $\begin{array}{l}\text { Mean removal } \\
\text { of lymphocytes } \\
(\%)\end{array}$ \\
\hline $\begin{array}{l}\text { Pall urispun } \\
\text { Pall spun }\end{array}$ & $\begin{array}{r}7 \\
29\end{array}$ & $\begin{array}{l}12 \\
40\end{array}$ & $\begin{array}{l}5 \\
8\end{array}$ & $\begin{array}{l}1 \cdot 44 \\
1 \cdot 13\end{array}$ & $\begin{array}{l}0.55 \\
0.5\end{array}$ & $\begin{array}{r}7 \\
29\end{array}$ & $\begin{array}{r}6 \\
22\end{array}$ \\
\hline $\begin{array}{l}\text { Fenwal unspun } \\
\text { Fenwal spun }\end{array}$ & $\begin{array}{l}28 \\
29\end{array}$ & $\begin{array}{l}45 \\
43\end{array}$ & $\begin{array}{l}6 \\
6\end{array}$ & $\begin{array}{l}1 \cdot 22 \\
1 \cdot 16\end{array}$ & $\begin{array}{l}0.72 \\
0.60\end{array}$ & $\begin{array}{l}28 \\
29\end{array}$ & $\begin{array}{l}17 \\
27\end{array}$ \\
\hline
\end{tabular}


the leucocyte microaggregates formed during storage. When blood stored in CPD-adenine is available in this country, its shelf-life will be prolonged up to six weeks. This should increase the amount of spontaneous aggregation of white cells and platelets before centrifugation, which in turn would increase the overall removal by filtration of white cells. However, older red cells will survive in the circulation of the recipient for a shorter time than younger red cells, which could reduce the time interval between transfusions.

Surprisingly, the Hemalog D automated differential counter was still able to differentiate between neutrophils and lymphocytes in CPD-stored blood, even after up to 21 days of storage at $4^{\circ} \mathrm{C}$. This instrument relies upon the peroxidase activity of neutrophils to distinguish them from peroxidase negative lymphocytes (Fig. 1A). Although the instrument's peroxidase oscilloscope display showed considerable differences between CPD-stored blood and fresh EDTA blood samples nevertheless lymphocyte and neutrophil populations could still be distinguished (Fig. 1B). By suitable readjustment of the instrument's thresholds (the boxes in Fig. 1) counts of neutrophils and lymphocytes were obtained. Degenerative changes in the leucocytes of 21-day-old stored blood made a morphological identification using conventional microscopy impossible. It was not possible to identify monocytes or basophils in the CPD-stored blood using the esterase and alcian blue channels of the Hemalog D.

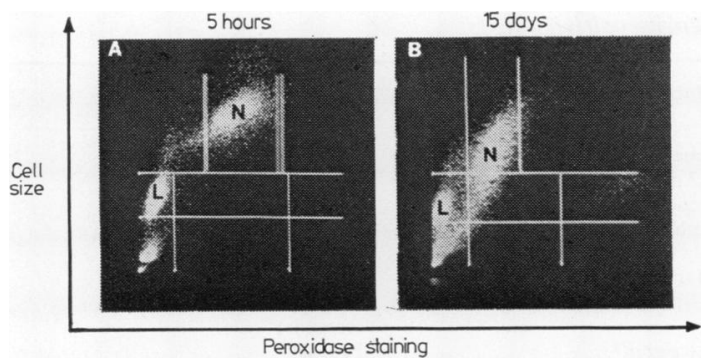

Fig. 1 (A) shows the Hemalog $D$ peroxidase display for normal blood. Neutrophils $(N)$ being larger and having moderate peroxidase activity are separate from lymphocytes $(L)$ of moderate size and having no peroxidase staining. After 15 days storage in $C P D$ at $4^{\circ} \mathrm{C},(B)$ lymphocyte $(L)$ and neutrophil $(N)$ populations may still be distinguished and counted by readjustment of the instrument's thresholds.
The fact that the Fenwal filter removes $28 \%$ of white cells when the blood units are uncentrifuged, whereas the Pall filter removes only $7 \%$, is probably because the pores in the Pall filter are $40 \mu \mathrm{m}$ wide, whereas those in the Fenwal filter are only $20 \mu \mathrm{m}$ wide; the Fenwal filter will therefore remove the smaller microaggregates before centrifugation.

There was little or no loss of red cells during filtration since these filters are used "in line" and do not require priming with normal saline. Filtrate from the entire unit enters the recipient. As both the Fenwal and Pall filters can be used for multiple units of blood there is little wastage of red cells, only those trapped in the filter at the end of its use will be discarded.

It would seem that the Pall and the Fenwal microaggregate filters are simple, and relatively inexpensive methods of reducing the numbers of white cells and platelets present in transfused blood. In the case of the Fenwal filter, it is not necessary to centrifuge the units before filtration. Both filters are simple to use and can be employed at the bedside, thereby reducing technician time spent on preparation of white cell-poor blood.

\section{References}

${ }^{1}$ Kevy SV, Schmidt PJ, McGinnis MH, Workman WG. Febrile, nonhaemolytic transfusion reactions and the limited role of leucoagglutinins in their aetiology. Transfusion 1962;2:7-15.

2 Payne R, Rolfs MR. Further observations of leucoagglutinin transfusion reactions, with special reference to leucoagglutinin transfusion reactions in women. Am J Med 1960;29:449-58.

${ }^{3}$ Andre R, Dreyfus B, Salmon C. Étude statistique des isoimmunisations antierythrocytes, antileucocytes et antiplaquettes observées chez 552 malades polytransfusés In: Proceedings of the 7th Congress of the International Society for Blood Transfusion. Rome, 1958:863-8.

4 Perkins HA, Payne R, Ferguson J, Wood M. Nonhaemolytic transfusion reactions. Vox Sang 1966;2: 578-600.

5 Wenz B, Gurtlinger K, O'Toole A, Dugan E. Preparation of granulocyte poor red blood cells by microaggregate filtration. Vox Sang 1980;39:282-7.

- McNamara JJ, Boatright D, Burran EL. Changes in some physical properties of stored blood. Ann Surg 1971;174: 58-60.

7 Swank RL. Alteration of blood on storage: Measurement of adhesiveness of "ageing" platelets and leucocytes and their removal by filtration. $N$ Engl J Med 1961;265: 728-33.

Requests for reprints to: Dr JG Treleaven, Department of Haematology, The London Hospital, Whitechapel, London E1 1BB, England. 